\title{
CURSING, SEXUAL HARASSMENT, PROFANITY, OBSCENITY AND EPITHET IN DALLAS BUYERS CLUB MOVIE
}

\author{
Imelda Woa Wene'; Ouda Teda Ena ${ }^{2}$ \\ Sanata Dharma University ${ }^{1,2}$ \\ Corresponding email: imeldawene@gmail.com
}

\begin{abstract}
Taboo words are words that are strictly prohibited to be used due to the fact that they may cause misunderstanding or conflict and are not appropriate. Therefore, it is important to understand taboo words in order to avoid using inappropriate words. This studyexamines the use of taboo words by the characters in Dallas Buyers Club movie. It focuses on the types of taboo words and reasons that influence the characters to use taboo words in the movie. This study used content analysis method as the research method. The sources of data were the movie and its transcription. The researchers obtained the data from the characters' utterances. This study finds there are five types of taboo words, namely cursing, profanity, obscenity, epithet and sexual harassment. Cursing is the most frequently taboo word used by the characters in the movie. The researchers also find that he reasons for using the taboo words are humor, psychological condition, ethnic group identity and social class. Psychological condition is the dominant reason for the characters' use of taboo words. The result of this study provides an in-depth understanding of the usage of English taboo words in movies that might influence young English learners.
\end{abstract}

Keywords: Characters, Dallas Buyers Club, Taboo words, Utterances

\section{INTRODUCTION}

Language has dynamic characteristics. It means that it changes over time. In modern era, the norm of using language is changing. The words that are considered as taboos in the old times are now considered to be common words. The use of taboo words nowadays is intense. People from different social status and ages may use taboo words during the conversations.

From generation to generation, taboo words are strictly prohibited to be used in society since it may cause misunderstanding or conflict. Radclifee 
and Brown (in Allan \& Burridge, 2006) state that taboo words mean simply 'to forbid', 'forbidden', and can be applied to any short of prohibition. Yule(2014) states taboo words are defined as words and phrases that are inappropriate for use in social communities, that is, words that are considered sacred, prohibited, or just inappropriate. Klerk (1992) enriches the definition of taboo words in the following way: "... tabooed words generally being culture-specific and relating to bodily functions or aspects of a culture that are sacred. Such words are avoided, considered inappropriate, and loaded with affective meaning" (p.277). Furthermore, Olsen (2018)accounts taboo words are prohibited or strongly discouraged from using them in connection with social relations. The use of taboo words is subject to sanctions and is limited to institutional and individual levels assuming that some harm will occur if the taboo word is pronounced (Jay, 2009b).

Many words and expressions are viewed as 'taboo', such as those used to describe sex, our bodies and their functions, religion matters and those used to insult other people.This is in line with Crystal's opinion (in Purba, 1998)that taboo word or linguistic taboo is any words that are generally related to sexual organs, the supernatural, excretion, religion matters, and death, but quite often they extend to other aspects of domestic and social life.Jay (2009)mentions that there are hundreds of taboo words and phrases. Knowing this fact, it is very necessary for language users to know the types of taboo words in order to have a deep understanding before using them in communication.

Ningjue (2010)formulates five types of taboo words, namely, cursing, profanity, obscenity, epithets, and sexual harassment. Cursing, according to Jay (1992)in his book Cursing in America: "The intent of cursing is to invoke harm on another person through the use of certain words or phrases" (p.2). Ningjue (2010)supports Jay's idea by stating: "Cursing is throwing negative hurtful damning words at somebody". When cursing, both the speaker and the listener understand what is going on. The speaker knows that the taboo words are expressed and the listener knows that the target of the taboo words is himself. Examples of cursing are fuck, damn, eat shit and die, and $i$ hope you break your neck.

Profanity is a religious term that usually leads to irrelevant words related to the use of the name of God or Deity and other religious terms. According to Battistella (2005), profanity involves the rough use of what is considered sacred. "The range of it is wide, from a mild hell or damn to a more emphatic goddamn" (Ningjue, 2010, p.6). Moreover, Jay (1992) describes:"An example of profanity would be a word or phrase which seeks not to denigrate God, religion or holly affairs but would be based more on ignorance of or indifference to these matters" (p.3). The common profanity 
expression employing religious terminology are Jesus fucking Christ, hell you, goddamn, and holly shit.

Obscenity, according to Battistella (2005), is words and phrases that characterize gender anatomical differences or sexual function and excretion in a crude way. Jay(1992)argues obscene words are considered to be the most offensive and are rarely, if ever, used in public media. Those words are motherfucker, cocksucker, fuck, shit, tits, or cunts.

Epithets are harsh words that refer to one's appearance, disabilities, and other characteristics that are considered lacking."Epithets are various types of slurs, such as wop, raghead, bitch, or fag. Usually these refer to race, ethnicity, gender, or sexuality, but they may also refer to appearance, disabilities, or other characteristics (as for example with the epithets midget, gimp, and retard)" (Battistella, 2005, p.72). The use of epithet is usually driven by frustration and anger directed at people and other objects. Jay (2009)also shares the same idea by stating: "Epithets are offensive emotional outbursts of single words or phrases used to express the speaker's frustration, anger, or surprise (Holy shit! Fuckme!)" (p.155).

Sexual harassment is distinguished verbally and physically. This type of taboo word has a great negative effect on the victim.Jay (2009) explains: "Verbal sexual harassment amounts to unwanted jokes of a sexual nature; references to a person's sexual behavior, body, or clothing; or pervasive offensive sexual comments. The mere utterance of an offensive word does not meet the conditions of sexual harassment, nor is speech that is not severe or pervasive enough to create an objectively hostile or abusive work environment-one that a reasonable person would find hostile or abusive" (p.82). In addition, Jay (1996a) also states that sexual harassment also relates to references that demean someone based on gender. Examples of sexual harassment arekiss myass, fuck meand $a$ dumb ass woman. These words are inappropriate to use in social interaction.

Although taboo words are considered taboo in society, using taboo words is also needed in some contexts. Olsen (2018) argues the use of taboo words, or swearing, can be considered a necessity in language, especially when studying it from a sociolinguistic perspective. This shows that besides having negative sides taboo words also have a positive side. There are many reasons that encourage people to use taboo words, and one of them is to express their feelings. "People, as a kind of emotional animal have a desire to express their feelings, relieve their negative stress, and establish their identities and status through their speeches" (Jay, 1999,p.84). He argues that the use of taboo words can help them achieve this goal effectivelysince language is a tool used by everyone. In this study, the researchers list the reasons for using taboo words. The first reason is humor. Although it is considered taboo and not polite, the jokes about sex are very popular among 
males and females on the internet (Ningjue, 2010). Mentioning something that is usually prohibited can reach a humorous effect. According to Jay (1999) the usage of taboo language could be positive when it occurs in circumstances like joking and sexual enticement.

The second reason is psychological condition. Psychological condition is the most influential factor in using taboo words. Jay (1999) in his book Why We Curse: A Neuro-Psycho-Social Theory of Speech explains: "The aggressive person learns aggressive curse words and uses them to express his/her aggression towards others; he/she perceives others on the basis how others use aggressive language. The sexually anxious person uses sexual terminology in a manner that exposes his/her underlying anxiety through hesitation, word choice, and avoidance. The sexually anxious person experiences and interprets sexuality of the self and others through a forbidden language of sexuality" (p.87). Furthermore, Crystal (in Jay, 1999), asserts that there are many daily examples of taboo words, usually profanities or obscenities, which express emotions such as hatred, antagonism, frustration, and surprise. By stating the statement, the two experts indicated that using taboo language by saying forbidden words, negative emotions such as anger, dissatisfaction, depression, can be very relieved. In this context, we can see that the use of taboo words can be both positive and negative.

Next is ethnic group identity. It is common knowledge that language is used in the construction of ethnic identity. The terms "ethnicity" and "ethnic identity" consist of characteristics that we consider important when defining who we are and others, both as individuals and as part of a larger group. In the United States, there are two dominant ethnicities namely black and white English. Milroy (in Macaulay, 2005) points out that race and ethnicity are prominent in American ideology. Africans stand out in their language called Black English which is different from Standard English. Thomas and Wareing (2004) state that European and African ethnicities differ from each other not only in terms of where they come from, religious beliefs, cultural practices, and the language people speak, but also in terms of their racial characteristics. According to Trudgill (2000) the relationship between language and ethnic groups may be a simple relationship of habits, reinforced by social barriers between groups.

The last reason for using taboo words is social class. Different social groups use different language varieties, and as experienced members of a speech community we must learn to classify speakers accordingly (Trudgill, 2000). People who come from upper class are considered polite in using language. In contrast, those who are from lower class or working class tend to use offensive or bad language in their daily interaction. Lower class people usually use emotions to speak rather than think. This is due to the 
difference in their social groups where he lower class or working class consists of uneducated people. Gray (in Aditia, 2011) has the same perspective by stating that it might be fair to say that many speakers of swear words come from anarchist or lower class backgrounds, and that they swear primarily as a way to distance themselves from mainstream society and strengthen their position as members of certain social groups.

Those reasons above do have an impact on why people use taboo words in their social interactions. The use of taboo words is increasing day by day. This situation is caused by the use of taboo words on American movies. Today, American movies dominate the cinemas throughout the world. People who are from different ages are interested in watching American movies, hence it makes them easy in knowing, learning, and even applying taboo words that they learn from the movies in their social interactions. Claire (1998) states that there is a system for rating American movies. The ratings do not say how good the movies are. They tell how much sex, nudity, violence and vulgar language are in them. In movie, taboo words always bring out social culture, education, and someone's identity. Taboo words in movie plot are representations of real life. The young English learners might be exposed to taboo words from movies. Those who like to watch American movies might be exposed to taboo words from the movies.

Taboo words have been the focus of research a long time ago (Jay, 1992; Klerk, 1992; Davis, 1989;Trudgill, 1972). Other researchers examine the use of taboo words by gender (Hashamdar \& Rafi, 2018; Gao, 2008). Hashamdar and Rafi (2018) investigate the relationship between social identity and taboo words used by men and women to express their anger. They also focus their research on the relationship between the using of taboo words in male and female participants who had a college degree and those who did not. Meanwhile, Gao (2008) examines the use of taboo language in the conversations of female, male and mixed gender in several episodes of the American TV series Sex and the City. Further, Gao analyzes the differences and the similarities of using taboo language in male and female speech in terms of gender differences, and conversational strategies in general.Unlike these two studies, this study aims to examine the taboo words used by the characters in Dallas Buyers Club movie. This study wants to see the use of the taboo words by the characters. Moreover, this study uses Dallas Buyers Club as the subject of this study because this movie was a Hollywood box office movie in 2013. The movie also won three awards at the 2014 Academy Awards. The movie received a lot of attention of many people around the world. There are many taboo words found in this movie that might influence the audiences. For these reasons, this study uses this movie as the subject of the study. 
Although the taboo words have long been the topic of research, it is still considered unsuitable for the research material especially in the world of education. Since the topic of taboo word is still considered as a taboo to be examined, a research on taboo words is very necessary in order to give a deeper understanding of the taboo word itself. It is important to inform everyone who always uses the taboo words in daily communication without knowing what taboo words are. This paper aims to examine taboo words used by the characters in Dallas Buyers Club movie based on the following formulated questions: 1) What are the types of taboo words found in Dallas Buyers Club movie?; 2) What are the reasons for the characters to use taboo words in Dallas Buyers Club movie? Through this study, the speaker and listener's attitudes to the use of taboo words can be seen so that the understanding of the use of the taboo words becomes deeper.

\section{METHODS}

\section{Sample}

This study used content analysis method as the research method.Research that uses qualitative content analysis focuses on the characteristics of language as communication by paying attention to the content or contextual meaning of the text (Hsieh \& Shannon, 2005; Tesch, 1990).This study focused on the taboo words of four main characters in Dallas Buyers Club movie. The four characters were Ron Woodroof, Rayon, Eve Saks, and Tucker. The research data were the movie and its script which was downloaded from https://thescriptsavant.com/pdf/DallasBuyersClub.pdf. The researchers obtained the data from the characters' utterances. Furthermore, theory of taboo words by Ningjue (2010)was used in this study to analyze the data.

\section{Instruments}

In this study, the researchers were the main instrument who obtained, interpreted, and analyzed the data. Peredaryenko and Krauss (2013) mentions that the researcher acts as main instruments in qualitative research. According to Turato (in Pezalla, Pettigrew, \& Miller-Day, 2012), "Researchers use their sensory organs to grasp the study objects, mirroring them in their consciousness, where they then are converted into phenomenological representations to be interpreted" (p.167). Moreover, the secondary instrument was data sheet. It was used to classify the data. The data sheet was provided in the form of a table to present the two objectives that were the focus of the study, namely, the types of taboo words and the reasons for using taboo words. 


\section{Data Analysis Procedures}

There were several steps followed by the researchers in this study. First of all, the researchers categorized the collected data into categorization system. Next, putting the selected utterances that contain taboo words into the table as raw data. After finishing the classification, the researchers analyzed the data to desribe the types of taboo words and the reasons for using taboo words in the dialogues. In addition, the researchers also employed quantitative methods in the analysis because it involved the number to obtain percentage of each phenomenon in the table. The fixed percentages then were used to support data interpretation. After that, the researchers confirmed the findings with the theory used in the analysis. The researchers then explained the findings to answer the research questions. The final step was reporting the findings and drawing the conclusion.

\section{FINDINGS}

\section{Types of Taboo Words Found in Dallas Buyers Club Movie}

This study finds 60 data of taboo words. The data are then displayed in Table 1. The frequency of the occurrence of the types of taboo words uttered by the four characters are shown in the table below.

Table 1. The Frequency of Taboo Words Emerged in This Study

\begin{tabular}{lll}
\hline Taboo Word & Frequency & Percentage \\
\hline Cursing & 32 & $53,33 \%$ \\
Profanity & 7 & $11,67 \%$ \\
Obscenity & 4 & $6,67 \%$ \\
Epithet & 14 & $23,33 \%$ \\
Sexual Harassment & 3 & $5 \%$ \\
\hline Total & 60 & $100 \%$ \\
\hline
\end{tabular}

The table 1 shows that the taboo word in the form of cursing is the most frequent taboo word used, and it is followed by epithet. Meanwhile, the least taboo words used is sexual harassment.

\section{Reasons for Using Taboo Words}

After analyzing the data, the researchers discover the reasons behind the characters' taboo words during the conversation in the movie. The interpretation of the reasons for using taboo words by the characters is done by looking at the context in which the characters use taboo words. In addition, the expressions that they show when using the taboo words are also observed.

As it is discussed in the literature review, there are four reasons why people use taboo words. The finding of the present study discovers all of the reasons used in the movie. The four reasons are described in the table below. 
Table 2. The Frequency of Reasons for Using Taboo Words

\begin{tabular}{lcc}
\hline Reasons for using taboo words & Frequency & Percentage \\
\hline Humor & 3 & $5 \%$ \\
Psychological condition & 50 & $83,33 \%$ \\
Ethnic Group Identity & 1 & $1,67 \%$ \\
Social class & 6 & $10 \%$ \\
\hline Total & 60 & $100 \%$ \\
\hline
\end{tabular}

From Table 2, it can be seen that psychological condition is the main reason for the characters used taboo words in Dallas Buyers Club. It occurs 50 times in the movie. The reasons for humor and social class are 6 times and 3 times. Moreover, the reason for ethnic group identity occurs only once.

\section{DISCUSSION}

In this section, the researchers discuss the findings in depth in order to answer the research problems of this study. Some data from the appendix are taken as examples to provide a complete explanation. This section consists of two parts. The first part deals with the types of taboo words in the Dallas Buyers Club movie and the second part is about the reasons for using taboo words.

\section{Types of Taboo Words in This Study}

This study finds five types of taboo words uttered by the four characters in Dallas Buyers Club movie. Those taboo words are cursing, profanity, obscenity, epithet, and sexual harassment. It means the five types of taboo words from Ningjue (2010)'s theory are used in this film.

\section{Cursing}

This study finds that cursing is the most dominant taboo words used by the characters in the Dallas Buyers Club movie. Cursing is described as negative hurtful damning words (Ningjue, 2010). It attempts to invoke harm on person(Jay, 1992). Cursing appears 32 times and 2 of them are presented below in italic and bold forms.

In the parking lot of Rodeo Stadium

Ron : "Tucker! I need you to arrest me!"

Tucker : "Fuck off, Woodroof!"

Ron : : Come on, man. No, shit!"

The word shit refers to taboo word because this word relates to negative hurtful damning word at somebody or something. In this case, the first speaker (Ron) is chased by the gamblers when he sees the second speaker (Tucker) who is a police officer. He asks a help from Tucker but he 
rejects to help Ron. Ron sees the gamblers are approaching him and he is worried. The word shitis used by Ron to express his worry.

On Tucker's Police Car

Ron : "Thanks for the lift, man. (Fell to ground) Fuck!"

Tucker :"You okay?"

Ron : :You rattled my brain."

Tucker : "What brain?"

In the dialogue above, the word fuck is concluded as taboo word because this word relates to negative hurtful damning word at somebody or something. In this situation, Ron is chauffeured by Tucker to his house. When arriving at his house, Ron starts to get out of the car but he is fallen. The word fuck is used by him to express his bad luck.

\section{Profanity}

Profanity refers to religious cursing. The words such as God and Jesus Christ which are considered holy by religious people are used as taboo words. McGregor as cited by Olsen (2018) describes: "Words with religious connotations are generally regarded as taboo in many cultures when they are used outside of the appropriate religious context with expressions such as, “God!”, alternatively, "Christ!” (p.13). In daily interaction, people use the words as religious cursing. Profanity appears 7 times in Dallas Buyers Club movie. The researchers provide 2 examples of profanity that can be seen as follows.

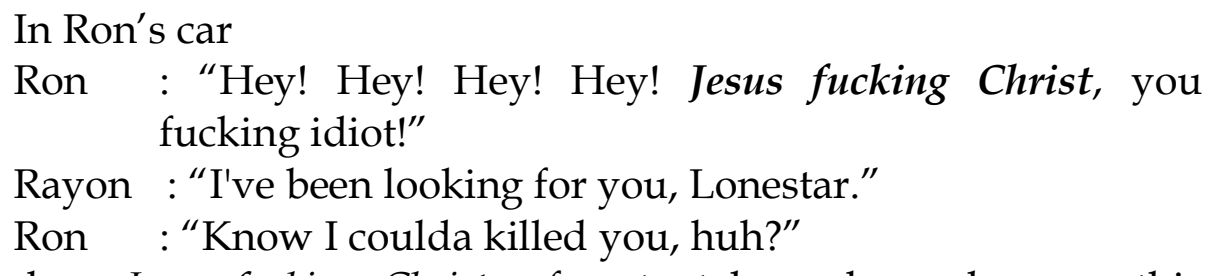

The phraseJesus fucking Christ refers to taboo phrase because this phrase relates to the irrelevant use of the name of God or Deity. In this case, Ron is counting his money when someone enters his car. Ron spontaneously takes his gun and points it to the person. When he realizes that the personis Rayon.Ron expresses his dejection by using the phraseJesus fucking Christ. The phrase Jesus fucking Christis expressed by Ron to show his emotion to Rayon who could die if Ron pulled the trigger.

In the hospital room

Rayon : "I guess you're handsome in a Texas hick, white trash, dumb kinda way."

Ron : "Get the fuck outta here, whatever you are, before I kick you in the fucking face. Goddamn."

In the dialogue above, the word goddamn refers to taboo word because this word relates to religious cursing that relates to the coarse use of 
what is taken to be sacred. In this case, Rayon, who is Ron's roommate in the hospital comes to Ron's bed then sits there. Ron is annoyed because he realizes that Rayon is a gay. The expression goddamn is expressed by Ron refers to his dejection.

\section{Obscenity}

Obscenity is considered as the most offensive taboo words and is restricted to be used in public media(Jay, 1992). It refers to gender anatomical differences or sexual function in a crude way. There are several obscene words found by the researchers in the movie.

In the locker room

Ron : "D'yahear Rock Hudson was a cock sucker?"

T.J : "Where d'ya hear that shit?"

Ron : "It's called a newspaper. Right there. It's a shame, ain't it? All that fine Hollywood pussy just all being wasted on a guy who smokes his fucking friends."

The word a cocksucker in the dialogue above refers to the taboo word due to it relates to comment about someone's sexual behavior. The first speaker (Ron) tells the second speaker (Tucker) if actor Rock Hudson is a homosexual man. The expression of a cocksucker is used as a description of Rock Hudson's sexual interest.

In the field oil

Ron : "Alright, Clinto, that shit is purer than a preacher's daughter's pussy right there."

Clint : "Not after you've just coughed your lungs all over it."

The phrasea preacher's daughter's pussy above is categorized as taboo phrase because this word relates to part of woman's private body. In this situation, Ron sells cocaine to Clint. He promotes the cocaine is purer by comparing with a body part of preacher daughter which is considered as ainnocent woman. This taboo phrase is used to emphasize the good quality of cocaine. This is in accordance with what Olsen (2018)states that "The occurrence of a taboo word will strengthen the impact of a statement considering how the word or words used are generally inappropriate in a conversation" (p.9).

\section{Epithet}

Epithet is kind of taboo wordswhich is used as an emotional language. Epithet uses the context of race, ethnicity, appearance, and disabilities to insult other person. That words that refer to epithet are bitch, midget and wop. The data below are the result and analysis of epithet and the words in italic and bold form are the taboo words of epithet.

In the oil field 
T.J : "Hey, you thinking anymore about Saudi Arabia? They need guys over there."

Ron : "Fuck, no. Why d'you wanna go work for a bunch of sand niggers anyway, huh?"

In the conversation above, the word niggers is categorized as taboo word since this word relates to race. In this situation, T.J asks Ron's decision about an offer to work in Saudi Arabia. Ron is not interested in the offer so that he answersthat he is not interested to work there. After that, Ron asks T.J what makes him want to work in Saudi Arabia. The word niggers is expressed by Ron in his question to T.J to insult Arabian who most of them got black skin and also to emphasize that he really is not interested at all to work there. The reason of using the word niggers is ethnic group.

In the hospital room

dr. Sevard : "Mr. Woodroof, have you ever used intravenous drugs? Have you ever engaged in homosexual conduct?"

Ron : "Homo? Did you say homo? Yep! That's what yousaid isn't it? Shit, you fucking kidding me'? I ain't no faggot, motherfucker! I don't even know no fucking faggots. Look at me. What d'you see, huh? The goddamn rodeo's what you see!"

The word faggot uttered by the character above is related to taboo word because this word refers to the appearance of someone. In this case,dr. Sevard asks his patient, Ron, if he ever engages in homosexual activity which also means that Ron is a homosexual man or bisexual. Ron is furious when he hears it, then he answers dr. Sevard that he is not a homosexual man. The word faggot is expressed by Ron who is furious withdr. Sevard. Jay (2009b) emphasizes that epithets are offensive emotional outbursts of single words or phrases used to express the speaker's frustration, anger, or surprise.

\section{Sexual Harassment}

Sexual harassment is sexual remarks which refer to sexual behavior, sexual looseness and body parts. It also refers to offensive sexual comments and demeans someone based on gender, for example, damn ass woman and big tits. These words are inappropriate to use in public because the meaning of the words will harm the listeners. The result and analysis of sexual harassment could be seen in data below.

$\begin{array}{ll}\text { In Ron's car } & \\ \text { Rayon } & \text { : You got enough for } 20 \text { of us? } \\ \text { Ron } & \text { :Yep! }\end{array}$


Rayon : You know what? You don't deserve our money, you homophobic asshole.

The phrase homophobic asshole isa taboo phrase because it relates to sexual behavior and body part that are rude and impolite to hear. In this situation, Rayon enters Ron's car and it makes Ron feel annoyed. Ron asks Rayon to get out from his car. Afterwards, Rayon asks Ron if he has medicine for 20 people who want to buy it. Ron is speechless at the first when he heard that there are 20 customers. He then answers yes. However, Rayon who already feels upset with Ron, tellshim that he does not deserve the money . Rayon uses the taboo word to insult Ron. The phrase homophobic asshole is expressed by Rayon to show his dejection.

At Ron's office

Rayon : "Well, maybe this will help." (giving money to Ron)

Ron : " "Where d'you get this? D'you sell your ass?

Really, where d'you get it?"

Rayon : : "I sold my life insurance policy. Not like I'm gonna need it anyway. Thank you."

The phrase sell your ass above refers to taboo word since this word relates to part of private body. The first speaker (Rayon) gives money that is from the sale of his insurance police to the second speaker (Ron). Ron knows if Rayon has not money anymore so he is curious how Rayon got much money so he asks Rayon. The word ass is expressed by Ron to show his disbelief about how Rayon can get much money.

\section{Reasons for Using Taboo Words}

In this section, the researchers discuss the reasons for using the taboo words by the four characters in the Dallas Buyers Club movie. These characters have strong reasons for using taboo words. Crystal and Peckham (in Olsen, 2018) explain that "Swearing, whether mild or strong, makes an excellent relief mechanism. It actually helps to turn on the inanimate object that has hurt you and berate it verbally... Or, if you would prefer a more literary allusion, swearing is a way to "unclog the heart.'..." (p.11). In this study, the four reasons for using taboo words are humor, psychological condition, ethnic group identity, and social class are explained through several examples below.

\section{Humor}

After doing the analysis, the researchers find the reason for using the taboo words as humor occurred 3 times. The use of taboo words such as joke about sex are expressed by the characters in the movie. The aim of using the taboo word is only for humor. People may find relief and positive effects of 
laughing at jokes, humour and sarcasm in which curse words are used (Jay, 1999). The researchers take one example produced by the character to describe humor as the reason for using the taboo words.

In dr. Vass's clinic, Mexico

dr. Vass : "Now you got chronic pneumonia, among other things. It can cause memory loss, mood swings, aching joints."

Ron : :If it sucks, I got it. I can't get my cock up, all that shit. If it is shit, I got it, don't I?"

The dialogue provides an example of the reason for humor. The second speaker (Ron) uses the word cock up in his utterance to make a joke about his condition. The use of taboo words can give positive outcomes. Jay (2009a) explains: "Positive social outcomes are achieved by using taboo words in jokes and humor, social commentary, sex talk, storytelling, ingroup slang, and self-deprecation or ironic sarcasm in order to promote social harmony or cohesion" (p.155). In this case, the use of taboo is intended for self-humiliation or ironic sarcasm.

\section{Psychological Condition}

When people get angry, they tend to use aggressive curse word to express their aggression and anger towards others. In this situation, the psychological condition is the factor which makes people use the taboo words. They express their emotion such as anger, dissatisfaction, and depression in a crude way. It is in line with the statement of Allan and Burridge (2006): "Language is used as a shield against malign fate and the disapprobation of fellow human beings; it is used as a weapon against enemies and as a release valve when we are angry, frustrated or hurt " (p.2). The reason for using taboo word as psychological condition in this study can be seen in the italic and bold form below.

In the hospital room

dr. Sevard : "Based on your health, on your condition, on all the evidence we have, we estimate you have 30 days left to put your affairs in order."

Ron : "Thirty days?"

dr. Sevard : "I'm sorry."

Ron : "Fuck this. This is shit. Fucking 30 day mother fuckers. Let me give y'all a little newsflash. There ain't nothing out there that can kill Ron Woodroof in 30 days."

From the dialogue, it can be seen that the second speaker (Ron) uses fuck to express his emotion of shock when he hearsthat he will die soon. The word fuck here is very needed to be uttered by Ron to express his emotion. 
Taboo words are connected not only to words that are considered inappropriate for use in particular social surroundings, but also what people tend to use to exclaim feelings, both positive and negative, and proffer opinions regarding particular types of matters (Olsen, 2018).

\section{Ethnic Group Identity}

Language is used by people in daily inteaction to express their ethnic identity. Through spoken language, we can find out which ethnic group the person came from, for instance, white Americans and black Americans use different ways of communicating. In this study, the use of taboo because of ethnic group identity factor occurred only once. The taboo word that is used by the character due to the ethnic group identity is presented in the dialogue below.

In the oil field

T.J : "Hey, you thinking anymore about Saudi Arabia? They need guys over there."

Ron : "Fuck, no. Why d'you wanna go work for a bunch of sand niggers anyway, huh?"

The using of taboo word on the dialogue above is to insult a race that is Arab. The second speaker uses the word niggers to emphasize the difference of skin color. In this case, the word Arab is replaced by the word niggers.

\section{Social Class}

Taboo words can be also used to express someone's social class. As it has been mentioned previously, the use of language of upper class people in their social groups is obviously different from that of lower class people. In other words, different social groups use different linguistic varieties (Trudgill in Aditia, 2011). However, McGregor (in Olsen, 2018) mentions that the relationship between different classes and their use of speaking in English is quite complicated by stating: "Broadly speaking, swearing has flourished most in the upper and lower or working classes, but not in the bourgeoisie or middle class" (p.12-13). Mcgregor's statement shows that the use of taboo words is not only by lower or working class but also by upper class. The example of using the taboo words by working class can be seen below.

In the locker room

Ron : "D'yahear Rock Hudson was a cocksucker?"

T.J : "Where d'ya hear that shit?"

Ron : "It's called a newspaper. Right there. It's a shame, ain't it? All that fine Hollywood pussy just all being wasted on a guy who smokes his fucking friends." 
In conversation above, the first speaker (Ron) utters the taboo word cocksuckerin order to replace the word homosexual. Ron who is from working class tells his workmates that actor Rock Hudson is a homosexual man. Using taboo words is a habit for Ron.

\section{CONCLUSION AND SUGGESTION}

The data from the movie shows that from 60 conversations in Dallas Buyers Club movie, there are 32 cursings, 7 profanities, 4 obscenities, 14 epithets and 3 sexual harassments. The most taboo word used in this movie is cursing. Meanwhile, sexual harassment is the least used taboo word. In this study, fivetypes of taboo words by Ningjue (2010) are found in the movie. Furthermore, several reasons influence the use of taboo words, namely humor, psychological condition, ethnic group identity and social class. The psychological condition reason is the one used most in the movie. The least used reason is ethnic group identity. The result of this study provides an indepth understanding of the usage of English taboo words in movies that might influence young English learners.

The researchers of this study acknowledge that this study still has limitation in which it only focuses on the use of taboo words by four characters in movie. Therefore, it is highly recommended that the future studies need to be conducted and the future researchers can conduct the same research by increasing the number of the characters to be studied. Moreover, it is really suggested that the future researchers conduct the same research in the other literary works.

\section{REFERENCES}

Aditia, H. (2011). an Analysis of Taboo Word and Swear Word in Dustin Lee Abraham' S How High Movie Letters and Humanities Faculty State Islamic University "Syarif Hidayatullah." Retrieved from http://repository.uinjkt.ac.id/dspace/bitstream/123456789/4861/1/H ENDRI ADITIA-FAH.PDF

Allan, K., \& Burridge, K. (2006). Forbidden Words Taboo and the Censoring of Language. New York: Cambridge University Press.

Battistella, E. L. (2005). Bad Language: are some words better than others? New York: Oxford University Press.

Claire, E. (1998). Dangerous English 200! An Indispensable Guide for Language Learners and Others (3rd ed.). Illinois: Delta Publishing Company.

Davis, H. (1989). What makes bad language bad? Language and Communication, 9(1), 1-9. https://doi.org/10.1016/0271-5309(89)90002-5

Gao, G. A. O. (2008). Taboo Language inSex and the City: An Analysis of Gender Differences in Using Taboo Language in Conversation. Kristinanstad University. Retrieved from http://www.diva- 
portal.org/smash/record.jsf?pid=diva2:224602

Hashamdar, M., \& Rafi, F. (2018). Social Identity and Use of Taboo Words in Angry Mood: A Gender Study. Theory and Practice in Language Studies, 8(6), 623. https://doi.org/10.17507/tpls.0806.11

Hsieh, H. F., \& Shannon, S. E. (2005). Three approaches to qualitative content analysis. Qualitative Health Research, 15(9), 1277-1288.

https:/ / doi.org/10.1177/1049732305276687

Jay, T. (1992). Cursing in America: A Psycholinguistic Study of Dirty Language in the Courts, in the Movies, in the Schoolyards and on the Streets. 273.

Retrieved from http://www.amazon.com/dp/155619451X

Jay, T. (1999). Why We Curse. Why We Curse. https:/ / doi.org/10.1075/z.91

Jay, T. (2009a). Do Offensive Words Harm People? Psychology, Public Policy, and Law, 15(2), 81-101. https://doi.org/10.1037/a0015646

Jay, T. (2009b). The Utility and Ubiquity of Taboo Words. Perspectives on Psychological Science. Perspectives on Psychological Science, 4(2), 153-161. https:/ / doi.org/10.1111/j.1745-6924.2009.01115.x

Klerk, V. De. (1992). How taboo are taboo words for girls? Language in Society, 21(2), 277-289. https:/ / doi.org/10.1017/S0047404500015293

Macaulay, R. K. S. (2005). Talk that Counts: Age, Gender, and Social Class Differences in Discourse. In Talk that Counts: Age, Gender, and Social Class DifferencesinDiscourse. https:/ / doi.org/10.1093/acprof:oso/9780195173819.001.0001

Ningjue, Z. (2010). Taboo language on the Internet: An analysis of genderdifferences in using taboo language.Kristinanstad University. Retrieved from http:/ /www.diva portal.org/smash/get/diva2:398136/FULLTEXT01.pdf

Olsen, J. H. (2018). Bachelor Thesis Bachelor's Programme in Linguistics , 180 credits Creating Verbal Weapons A Sociolinguistic Study on Taboo Words and Acceptance in Social Communities Bachelor Thesis , 15 credits.

Peredaryenko, M. S., \& Krauss, S. E. (2013). Calibrating the human instrument: Understanding the interviewing experience of novice qualitative researchers. Qualitative Report, 18(43), 1-17.

Pezalla, A. E., Pettigrew, J., \& Miller-Day, M. (2012). Researching the researcher-as-instrument: An exercise in interviewer self-reflexivity. Qualitative Research, 12(2), 165-185. https://doi.org/10.1177/1468794111422107

Purba, R. (1998). Linguistic taboo in Simalungun a sociolinguistic study. IKIP Malang.

Tesch, R. (1990). Qualitative research: Analysis types and software tools. In Evaluation Practice (Vol. 12). https:/ / doi.org/10.1016/08861633(91)90027-u

Thomas, L., \& Wareing, S. (2004). Language, Society and Power: An 
Introduction.

Trudgill, P. (1972). Sex, covert prestige and linguistic change in the urban British English of Norwich. Language in Society, 1(2), 179-195. https:/ / doi.org/10.1017/S0047404500000488

Trudgill, P. (2000). Sociolinguistics: An Introduction to Language and Society. Penguin Books, 243. https://doi.org/10.2307/326846

Yule, G. (2014). The Study of Language (5th ed.). Retrieved from http:/ / bibliotecavirtual.unad.edu.co:2048/login?user=proveedor\&pass =danue0a0\&url=http:// bibliotecavirtual.unad.edu.co:2051/login.aspx? direct $=$ true $\& \mathrm{db}=$ nlebk\&AN=387929\&lang=es\&site $=$ edslive\&ebv=EK\&ppid=Page-_ -42 